\title{
Cumhuriyet dönemi çevreci bir yapı: Türkiye Ağaç Koruma Cemiyeti (1928- 1955)
}

\author{
Ufuk Erdem ${ }^{\mathrm{a}, *}$ (D)
}

\begin{abstract}
Özet: Türkiye Cumhuriyeti’nin kuruluşundan sonra başlayan yeniden yapılanma döneminde toplumun da bilgi ve kültür anlamında donatılması için politikalar üretilmiştir. Bu politikalar çoğunlukla devlet tarafından uygulanmakla birlikte -sınırlı da olsa- bazı yarı resmi sivil toplum kuruluşlarının da sürece dahil oldukları görülmektedir. Bu sürece katılım sağlayan yapılardan birisi de Türkiye Ağaç Koruma Cemiyetidir. Cemiyet, ülke genelinde ağaç sevgisini bireylere kazandırmak, çevre bilinci uyandırmak, meyve ağaçlarının ıslah edilerek yüksek kaliteli meyveler yetiştirip uluslararası piyasada rekabet edebilmek ve ülke genelini ağaçlandırmak gibi çalıșmalar yürütmüştür. Ayrıca Cemiyet ağaçlandırmayı özendirmek ve ağaca gösterilen sevginin toplumun tüm kesimlerine yayılmasını sağlamak için de Ağaç Bayramları düzenlenmesine öncülük etmiştir. Bu çalışmada Türkiye Ağaç Koruma Cemiyetinin kuruluşu, programı, nizamnameleri, faaliyetleri arşiv belgeleri ve dönemin gazeteleri 1şığında kronolojik olarak ele alınmıştır.
\end{abstract}

Anahtar kelimeler: Türkiye Ağaç Koruma Cemiyeti, Ağaç Bayramı, Cemiyet

\section{An environmentalist organization in the republic period: Turkish Tree Conservation Association (1928-1950)}

\begin{abstract}
The reconstruction period following the establishment of Turkish Republic encountered policies for providing the society with knowledge and culture. Although these policies were usually implemented by the government, few quasi-official non-governmental organizations, one of which was Turkish Tree Conservation Association, got involved in the action. The Association carried out such projects as raising naturalism among the individuals across the country, awaking environmental awareness, ensuring competition within the international market via growing high-quality fruits by tree-breeding, and contributing to country-wide afforestation. Moreover, the Association pioneered the organizations of the Tree Festivals for encouraging afforestation and ensuring the dissemination of love for tree amongst all segments of the society. The present study elaborates on Turkish Tree Conservation Association in such aspects as the establishment, programme, regulations and activities chronologically in the light of the archival documents and newspapers of the period.

Keywords: Turkish Tree Conservation Association, Tree Festival, Association
\end{abstract}

\section{Giriş}

Osmanlı Devleti'nde cemiyetlerin (derneklerin) ortaya çıkışı, yasal bir çerçevesi olmamakla birlikte, 1860'ların sonlarına doğru artmıştır (Arslan, 2010). Cemiyet kavramının gelişimi noktasında Tanzimat Fermanı ile başlayan, Kanun-i Esasi'yle devam eden süreç İkinci Meşrutiyet Dönemi'nde en üst seviyelere ulaşmıştır. İkinci Meşrutiyet Dönemi Osmanlı sivil toplum anlayışının yaygınlık kazandığı ve sivil örgütlenmelerin ön planda olduğu bir zaman dilimi olmuştur (Erdal ve Aydın, 2017). Nitekim bu dönem kendisinden sonraki yılları önemli ölçüde etkilemiştir. Örneğin 1909 yılında çıkarılan Cemiyetler Kanunu'nun 28 Haziran 1938 tarihine kadar bazı madde değişiklikleriyle yürürlükte kalmıştır (Toprak, 1985).

Cumhuriyetin ilanından sonra siyasi alanda faaliyet gösteren cemiyetlerin sayısında büyük oranda azalma yaşanmış, hemen hemen bilgi ve kültür gayesiyle kurulanlar dıșında cemiyet kalmamıştır (Hanioğlu, 1993). Bu bağlamda Türkiye Ağaç Koruma Cemiyeti de bilgi, kültür ve çevre bilinci ile ağaç sevgisinin topluma kazandırılması gayesiyle kurulmuştur. Bununla birlikte kurulduğu dönemin siyasi koşullarının şekillendirdiği Cemiyetin yapısını tam bir sivil toplum örgütü olarak tanımlamak güçtür. Özellikle ulus devletin kuruluş aşamasında idari-bürokratik seçkinler, toplumun aydınlatılması, yönlendirilmesi, modernleştirilmesi noktasında merkezden çevreye ya da yukarıdan aşağıya doğru siyasi sistemin belirleyicisi ve uygulayıcısı olmuşlardır. Bu noktadan hareketle Cemiyetin başkan ve üyelerinin milletvekili, vali, kaymakam, belediye başkanı, Danıştay üyesi vb. kimliklere sahip olması Cemiyet için yapısal olarak yarı resmi yarı sivil değerlendirmelerine yol açmıştır (Uluöz, 1945).

23 Nisan 1920'de Büyük Millet Meclisinin açılmasıyla her alanda olduğu gibi ormancılık alanında da çalışmalar başlatılmıştır. 11 Ekim 1920 tarihinde Cumhuriyet döneminde ormancılık ile ilgili ilk kanun olan Baltalık Kanunu çıkarılmıştır. Bu kanun ile öteden beri odunculuk, kömürcülük, kerestecilikle uğraşan ve büyük ormanlara en çok $20 \mathrm{~km}$ uzaklıkta bulunan köylülere hane başına on sekiz

\footnotetext{
$\bowtie$ a Ankara Hacı Bayram Veli Üniversitesi, Polatlı Fen-Edebiyat Fakültesi, Tarih Bölümü, Türkiye Cumhuriyeti Tarihi Anabilim Dalı, Ankara

@ * Corresponding author (İletişim yazarı): ufuk.erdem@hbv.edu.tr

$\checkmark \quad$ Received (Geliş tarihi): 28.05.2021, Accepted (Kabul tarihi): 15.07.2021
}

Citation (Atıf): Erdem, U., 2021. Cumhuriyet dönemi çevreci bir yapı: Türkiye Ağaç Koruma Cemiyeti (1928-1955). Turkish Journal of Forestry, 22(3): 295-305. DOI: $\underline{10.18182 / \mathrm{tjf} .944178}$ 
atik (1.8 hektar) baltalık verilmesi yoluna gidilmiştir. Ancak kanun baltalık ormanların tahrip edilmesi ve adaletsiz olduğu kadar teknik bir temele dayanmadığından üç yıl sonra Devlet Ormanlarından köylülerin İntifa Hakkı Kanunu ile yürürlükten kaldırılmıştır (Gülen ve Özdönmez, 1981). 1921 yılının başında İktisat Vekâleti TBMM Başkanlığına bir yazı göndererek Anadolu'da şehir, kasaba ve çıplak bölgelerin tespit edilmesi ve mülki memurların başkanlığında ağaç dernekleri kurulması, sürdürülmesi ve faaliyetleri konusunda icap eden muamelenin ifa buyurulması istenmiştir. Başkanlık da ilgili yazıyı Dâhiliye Vekâletine havale etmiştir (BCA, 1921) ${ }^{1} .17$ Şubat-4 Mart 1923 tarihlerinde düzenlenen İzmir İktisat Kongresi'nde ekonomik bağımsızlık sağlamak için düzenlemeler yapılırken ormanların korunması ve çoğaltılmasına yönelik kararlar da alınmıştır (IBBB, 2004). 7 Şubat 1924 tarihinde 76 gün görev yapabilen Orman Yüksek Meclisi (Orman Meclisi Alisi) kurulmuştur. 1924 yılı Bütçe Kanunu çerçevesinde İstanbul, İzmir, Bolu, Eskişehir, Adana, Menteşe, Antalya, Trabzon'da 1929 yılına kadar hizmet edecek olan Orman Başmüdürlükleri oluşturulmuştur (Gümüş, 2014). Yine 1924 yılında çıkarılan 442 sayılı Köy Kanunu ile her köylüye yılda bir ağaç dikme yükümlüğü verilmiştir. Ayrıca kanunla köylerde ağaçlandırma yapılması, orman veya koru yetiştirilmesi, konularında düzenlemeler yapılmıştır (Kutluk, 1936; Gümüş, 2018). Meclisin açılışından Türkiye Ağaç Koruma Cemiyetinin kurulduğu tarihlere kadar geçen sürenin cumhuriyet dönemi orman politikaları açısından inceleme araştırma ve karar verme devresi olduğu anlaşılmaktadır. Bu dönemde bir taraftan geleneksel yöntemlerle ormanlardan yararlanılmaya devam edilirken diğer taraftan da yüksek ve kaliteli üretim için bilimsel araştırma faaliyetleri sürdürülmüştür. Ülkenin yeniden imar edilmesi için ormanlardan yararlanma zorunluğu ortadayken bir taraftan da orman yetiştirme ve ağaç sevgisini millete aşılama yolunda çalışmalar yapılmıştır (Benli, 2014). Türkiye Ağaç Koruma Cemiyeti de bu çalışmalara Anadolu'nun pek çok bölgesinde şubeler açarak önemli katkılar sunmuştur.

\section{Materyal ve yöntem}

Araştırmanın ana materyalini Türkiye Cumhuriyeti Cumhurbaşkanlığ Devlet Arşivleri Başkanlığ Cumhuriyet Arşivinden temin edilen belgeler ile Milli Kütüphaneden elde edilen süreli yayınlar (gazete ve dergiler) oluşturmuş olup, ayrıca konuya ilişkin araştırma ve inceleme eserlerden de faydalanılmıştır. Elde edilen veriler tarih araştırmalarında kullanılan sınıflandırma, tahlil ve tenkit yöntemleriyle sentez edilmiştir. Konu kronolojik olarak ele alınmış ve açıklama dipnotları ile araştırmanın daha da anlaşılır olmasına çalışılmıştır.

\section{Bulgular}

\subsection{Cemiyetin kuruluşu ve ilk yilları}

\footnotetext{
${ }^{1}$ Dâhiliye Vekaletinin başkanlığın talimatıyla ilgili ne gibi bir işlem yaptığı bilin(e)memekle beraber, sonraki yıllarda konunun takipçisi olduğu anlaşılmaktadır. Nitekim Alanya'da Himaye-i Eşcar Derneğinin Dâhiliye Vekâletinin 11 Eylül 1928 tarih ve 2903/404 say1lı bir yazısına binaen kurulduğu ifade edilmektedir (Gönüllü, 2008).
}

İlk adı Himaye-i Eşcar Cemiyeti olan Türkiye Ağaç Koruma Cemiyeti, Cemiyetler Kanunu'na göre 20 Şubat 1928 tarihinde Kemah'ta kurulmuştur. Cemiyetin kurucusu olan Kemah Kaymakamı Hamdi Nafi Bey kuruluşu şöyle anlatmaktadır: Kemah'ta bulunan ağaç muhiplerini bir araya topladim. Mektebin ufak bir odasinda uzun münakaşat neticesinde Kemah Himayei Eşcar Cemiyeti ismini taşlyan bir cemiyet tesis ettik ve yirmi maddelik bir nizamname yaptık. Cemiyet Kemah'ta kaldığı kısa süre içerisinde bir fidanlık tesis ederek -bu alanda yetiştirip dağıtmak üzere- kayısı çekirdekleri dikmiştir. Ayrıca suni orman tesisi denemesinde bulunarak tedarik edilen akasya tohumlarını muhtelif mevkilere ekmiştir. Bu çalışmalar 80 dönümlük bir alana ulaşmıştır (Hamdi Nafi, 1929).

İktisat Vekili Rahmi Bey, Doğu Anadolu Bölgesi'nde tetkik seyahati yaptığı sırada Kemah'a da uğramış ve cemiyetin faaliyetlerini görerek takdir etmiştir. Rahmi Bey, Kemah Himayei Eşcar Cemiyetinin bölgesellikten çıkarılıp ülke genelinde yaygınlaştırılması için Ankara'ya nakledilmesinin daha uygun olduğunu ifade etmiştir. Bu direktif doğrultusunda taşınma işlemi gerçekleşmiş ve böylelikle Türkiye Himayei Eşcar Cemiyeti 13 Aralık 1929'da Ankara'da faaliyetlerine başlamıştır (Hakimiyeti Milliye, 25 Teşrinievvel/Ekim 1930). Cemiyetin merkezinin Ankara'ya taşınmasıyla birlikte Kemah'taki dosyalar sonradan Ankara'ya istenmiştir (BCA, 1932).

Himayei Eşcar Cemiyeti Başkanlığına seçilen ${ }^{3}$ Rahmi Bey 7 Ocak 1930 tarihinde Hakimiyeti Milliye gazetesine A ğaçları Koruma Millî Bir Borçtur başlığıyla Cemiyetin kuruluş ve amaçları hakkında şöyle bir beyanatta bulunmuştur*:

İki sene evvel Kemah'ta doğup memleketin sekiz vilayet merkeziyle 45 kazasinda, birçok köylerde ve nahiyelerde çoğalmış, büyümüş ve çalışmağa başlamış bulunan Himayei Eşcar Cemiyeti faaliyetini bütün memlekete yaymak için Ankara'yı merkez ittihaz etti. Bir ay evvel kongre topland,, umumî merkezin ve idare heyetini intihap ederek Ankara'da çalışmă̆a başladı.

Malûm olduğu veçhile ormanlar bir memleketin en mühim servet menbalarından biri olduğu gibi ziraatın de en mühim mesnetidir. Bazı seneler müthiş seller yüzünden en feyizli ovalarınızdaki mezruatın mahvolduğunu teessürle görürüz. Bunun yegâne sebebi, ormanlarda ve bilhassa meyilli arazide ăgaçların yakılarak, kesilerek tarla haline konmasından ve yağmur sularının bu açılmış tarla

\footnotetext{
2 Ankara'ya taşınan Cemiyetin isminin Ağaç Yetiştirme ve Ağaçları Taarruzdan Esirgeme Cemiyeti olması yönünde görüş beyan eden yazılar da bulunmaktadır. Konu hakkında bkz. Íctihad, 15 Temmuz 1930.

${ }^{3}$ Cemiyetin Ankara'ya taşınmasından sonra Dâhiliye Vekili (İçişleri Bakanı) Şükrü Kaya'nın bir müddet Cemiyetin başkanlığını yaptığına dair kayitlar da mevcuttur (Vakit, 10 Ağustos 1930). Ancak Vakit gazetesindeki haber dışında Şükrü Kaya'nın Cemiyet başkanlığını yürüttüğüne dair bir bilgi olmadığından gazetenin bu haberi şüphelidir. Diğer taraftan Rahmi Bey'in hangi tarihte ilk başkanlığa seçildiğine dair açık bir kayıt bulunmamaktadır. 2 Aralık 1929 tarihli Hakimiyeti Milliye gazetesi Cemiyetin umumi kongresini İktisat Vekaletinde yaptığını haber vermektedir. Haberin devamında perşembe günü genel idare heyetinin seçileceği ifade edilmiştir. Yapılan seçimle ilgili bilgi olmamakla beraber bir ay sonra çıkan haberlerin 1şığında Rahmi Bey'in 5 Aralık 1929'da yapılan bu seçimle cemiyet başkanlığına getirildiği anlaşılmaktadır.

* Gazetelerden alınan doğrudan alıntılarda günümüz dilbilgisi ve imla kurallarına uymayan çeşitli yanlışlıklar bulunmaktadır. Ancak bu yanlışlıklar anlam bütünlüğünü bozmadığından metinlere genel olarak müdahale edilmemiştir.
} 
topraklarım sürükleyip ovalara indirmesindendir. Her sene binlerce dönüm en kuvvetli arazimizin bereketli yetiştirme kudretini dağlardan gelen bu taşlı kumlu seller azaltmakta ve ekilmiş tarlalar bozarak yeniden tohum atmak mecburiyetini doğurmakta ve temizlenmiş nadas edilmiş tarlalar birçok muzır nebat tohumlarıyla bozulmaktadır. Yer yer biriken sel sularının teşkil ettikleri gölcükler de köylerin sihhatini bozmaktadır. Medenî memleketler bu afetlerin önüne geçebilmek için ziraat islahatında evvela suların tanzimini düşünerek orman mahallerinde gayri fennî kat'iyatın, tahribatın önüne geçmek için en kuvvetli inzibat tedbirleri almışlardır. Orman mıntıkalarında nüfus iskânını men ve hayvan rayın zarar vermeyecek yerlere hasr ve bilhassa dik meyilli araziyi muhafaza ormanlarina terk ederek su membaların kurutan; dere ve nehirlerin suların azaltan; iklimin itidalini bozan hallerin önüne geçmişler ve bentler, kanallar, cetveller açarak suların tahrip kuvvetini; istihsali iki üç misli arttıran ve emniyet altına alan feyizli bir kudret haline koymuşlardır.

Memleketimizde de ilim ve fennin bu kat'î icabatını nazarl dikkate alan hükümetimizin orman ve su siyasetinde esaslı bir programla faaliyete başladı̆̆ malûmunuzdur. Halkta uzun senelerin biraktı̆̆ fena itiyatlarl gidererek yerine ăgaç sevgisi uyandırmak için hükümetin giriştiği büyük mücadeleye halkın kendiliğinden doğan teşkilatlarla iştirak etmesi zaruri idi. Cemiyetimiz işte bu mühim maksat ve gayeleri temin etmek azmiyle çalışmağa başlamıştır.

Büyük Başvekilimiz cemiyetimizin; fahrî riyasetini kabul buyurmak suretiyle teveccüh izhar buyurdular ve klymetli himayeleri altına aldilar.

Cemiyetimizin kısa bir zamanda bütün memleket evlatlarının kalbinde şuurlu bir sevgiyle yaşamasında ve süratle inkişafinda bu himaye çok müessir olacaktır. Cemiyet umumî merkezi topland ve programın tespit etti (Hakimiyeti Milliye, 7 Kanunisani/Ocak 1930).

1930 yılı Şubat ayı içerisinde cemiyetin çalışmalara başladığı haberlere yansımıştır. Bu tarihe kadar Refahiye, Maraş, Çorum, Mecitözü, Osmancık, Alaca, İskilip, Sungurlu, Mersin, Tarsus, Kütahya, Eğriköy, Tavşanlı, Uşak, Simav, Gediz, Tekirdağ, Şarköy, Saray, Çorlu, Hayrabolu, Malkara, Diyarbakır kaza ve nahiyeleriyle Çanakkale ve Balıkesir'de şubeler açılmıştır. Şubeleşme faaliyetleri dışında Cemiyet, Ankara civarında meyve yetiştirmek için çeşitli yerlerden aşı için meyve çubukları getirtme işine girişmiştir. Bu meyve çubukları içerisinde Bursa'nın şeftalisi, İzmir'in sarı et şeftalisi, Çeşme'nin diş bademi, Kastamonu'da yetişen misket elması ve üryani eriği, Zonguldak'ın yağ armudu, Tokat'ın cezvit eriği, Yozgat'in seydibal armudu, Amasya'nın misket elması, Gümüşhane'nin gelin elması, Malatya'nın kayısısı, Mersin'in şekerpare kayısısı, Erzincan'ın mığrık armudu, Kağızman'ın tüysüz şeftalisi ve ahududu, Konya'nın şeker armudu, Kütahya'nın vişnesi, Niğde'nin şekerpare kayısısı yer almaktadır (Hakimiyeti Milliye, 6 Şubat 1930). Cemiyet, çeşitli bölgelerde küçük fidanlıklar yetiştirip dağıtmaktansa merkezi bir alanda büyük bir meyvelimeyvesiz fidanlık tesis edip dağıtma fikrini benimsemiştir. $\mathrm{Bu}$ amaçla cemiyet yönetimi Yerköy (Yozgat) civarında tetkiklerde bulunmuştur (Hakimiyeti Milliye, 12 Şubat 1930). ${ }^{4}$

\footnotetext{
4 Cemiyetin haberde bahsedildiği gibi bir merkezi fidanlık kurup faaliyete geçirdiğine dair kayıt bulunmamaktadır.
}

Cemiyet Mart ayı içerisinde Kastamonu'dan yüz kadar elma ve erik fidanı getirterek bunları bir liradan dağıtmıştır. $\mathrm{Bu}$ tarihe kadar 200 binin üzerinde meyve fidanı dağıtımı yapmıştır. Aynı ay içerisinde Cemiyet, ülke genelinde Ağaç Bayramı yapılması için bir talimat hazırlayarak iklim ve bölgenin uygunluğuna göre Ağaç Bayramı yapılmasını şubelerine bildirmiştir. $\mathrm{Bu}$ talimattan sonra ilk olarak Dursunbey, Uşak, Kemah, Geyve, Sivas ve Beyşehir'de bayram icra edilmiştir. Cemiyet, bu bayramlar sırasında gelir elde etmek için bayramlarda kullanılmak üzere rozetler hazırlayarak şubelerine göndermiştir. Ayrıca şubelerde kullanılmak üzere de 200 kadar mühür yaptırılarak şubelere gönderilmiştir (Hakimiyeti Milliye, 23 Mart 1930).

Cemiyet Mayıs ayı içerisinde gazeteye ilan vererek ülke genelinde neler yapılması gerektiğini şöyle duyurmuştur:

Memleketimizin en mühim irat membalarından ve harice yaptı̆̆ımız ihracat maddelerinin en mühimlerinden birisi de ăgaç ve ăgaç mahsulleri olduğu malûmdur. Memleketimizin birçok yerlerinde meyvalı ve meyvesiz ağaçlar pek çok olduğu halde diğer yerlerindeki dağlar, ovalar, tarlalar, nehir kenarları boş ve ağaçsızdır. Memleketimizin bugün ă̆açtan elde ettiğ faydalar memleketimizin kabiliyetinden pek dundur. Diğer taraftan mevcut ăgaçlar dikkatsizlikten ve hayvanatın zarar vermesi yüzünden harap olmaktadır, Işste memleketimizin bu klymetli servet membainı yükseltmek ve halkımızın ăgaçtan yaptı̆̆ istifadeyi azamî miktara iblă̆ etmek için Himayei Eşcar Cemiyeti teşkil edilmiştir.

$\mathrm{Bu}$ cemiyet her tarafta arazinin kabiliyetine göre yetişmesi lâzım gelen ă̆acın çoğalması için fidanlıklar tesis edecek ve burada yetişecek fidanları aşıladıktan sonra halkımıza tevzi edecek, boş ve çıplak araziyi sun'î usullerle teşcir ederek köylerimizi, dağlarımızı yeşillendirecek ve ă̆açların muhafazası için çalışacaktır. Cemiyetimizin yapacağı işlerden birisi de su kenarlarında kavak, sögüt gibi çabuk yetişen ve herkesin her zaman işine yarayan ăgaçlart çoğaltmaktır. Memleketimizin her tarafinda şehirlerimizde, köylerimizde birçok akarsular vardır bunların etrafinda sayısız ăgaçlar yetişebilir; böyle olduğu halde bu derelerin kenarlart ekseriya ăgaçsızdır. Burada bulunan köylerde ekseriya odunsuzluktan müşkülat çekerler. Hâlbuki bu ăgaçlart yetiştirmekte müşkülat yoktur. İş yalnı kavak ve söğ̈̈dün dalını kesmek ve bu dalları bu ağaçların yanına dikmektir; bundan sonra artık hiçbir masraf ve zahmet yoktur.

Bir aile reisi doğan her çocuğu için köyünün yanındaki dereye birkaç yüz ăgaç dikse çocuğu büyüyünceye kadar ăgaçlar da büyür ve çocuğu çalışacak çăga gelince kendine yapacağı iş için hazır bir sermaye bulur ve hayata atıldı $\breve{g}$ zaman sermaye bulmak müşkülatından kurtulmuş olur. Bu kadar az emekle bu kadar çok faydayı kaçırmamak lâzımdır.

Tarlalarımızın etrafina, derelerimizin kenarlarına meyval, meyvesiz ăgaçlar dikelim; ăgacın en kısa zamanda çok fayda veren kârlı bir iş olduğunu daima düşünelim (Hakimiyeti Milliye, 5 Mayıs 1930).

Cemiyet, 1 Aralık 1930'da Çocuk Sarayı Apartmanı'nda toplanan kongresinde bir yıllık faaliyetlerini anlatmış ve 1929 yılı hesabı kapatılırken 1930-1931 yıllarına ait bütçesi de ibra edilmiştir. Buna göre gider olarak; ağaçlandırma için 3 bin, hastalık ve haşeratla mücadele için 3 bin, merkez idare masrafları için de 3 bin liralık bir bütçe ayrılmıştır. Gelir olarak; devlet genel bütçesinden 5 bin liralık yardım, Ziraat Bankası ve Evkaf İdaresinden 2 bin liralık yardım, bağış ve üye aidatlarından temin edilecek 3 bin lira ile toplam 10 bin liralık bir hesap yapılmıştır (Hakimiyeti 
Milliye, 3 Kanunuevvel/Aralık 1930; Akşam 4 Kanunuevvel/Aralık 1930).

Kongrede ağaç uzmanlarının katılımıyla bir program hazırlandığı 3 bin nüsha basılarak şubelere ve ilgili yerlere dağıtıldığı bildirilmiştir. ${ }^{5}$ Genel merkez Ankara'da açıldığında 9 vilâyet, 25 kaza ve 24 nahiyede teşkilatı olan Cemiyet, bir yıl içerisinde bu sayıı 29 vilayet, 80 kaza ve 52 nahiyeye çıkarmıştır. Birçok vilayette yetişen ve diğer bölgelerde yetişmesi mümkün olan iyi cins meyvelerin yaygınlaştırılması için aşı kalemleri oluşturulmuştur (bu kalemlerin miktarı 77 çeşitte 3300'dür). Bu çeşitlerden 180 kalem Keskin ve Turgutlu'ya ve 222 kalem Tarsus ve Sivas şubelerine, 508 kalem Geyve, Kalecik ve Akhisar kazalarına, 579 kalem Edirne fidanlığına gönderilmiş ve 1817 kalem de Ankara'da meyve ağacı olanlara dağıtılmıştır. Bunun dışında Gaziantep'ten getirtilen fistık aşıları İstanbul, Aydın, Antalya, Bilecik vilayetleriyle Geyve kaymakamlığına gönderilmiştir. Aynı zamanda sakız ağaçlarının aşılanması için teşviklerde bulunulmuştur. İzmir bölgesinde yetişen fistık çamının diğer vilayetlerde çoğaltılması için Bergama'dan 30 kilo tohum getirilmiş ve Kocaeli, Antalya, Kırklareli, Afyon, Kütahya, Konya, İstanbul, Bursa, Artvin, Erzincan, Erzurum, Sivas, Rize, Kastamonu, Çankırı, İzmir, Çorum, Isparta, Denizli ve Adana vilâyetlerine, Tarsus kazasına, Devlet Demiryolları Eskişehir Fidanlığına, Ankara Ziraat Mektebine, orman fidanlığına gönderilmiştir. Buralardan alınacak sonuçlara göre ilerleyen yıllarda bu teşebbüsün arttırılmasını planlanmıştır. Erzincan'da ağaçlaştırılacak sahaya dikilmek üzere İstanbul Orman Mektebinden akasya, gladiçya, maklora, ıhlamur, çınar tohumları istenmiştir. İlkbaharda kavak ve söğüt gibi çabuk yetişen ağaçlar dikilmesinin teşviki için her tarafa tamimler gönderilmiştir. $\mathrm{Bu}$ çalışmalardan sonra ilkbahardaki ağaç dikme mevsiminde 36 türden 1.451 .934 ağaç dikilmiştir. İklim itibariyle benzer vilayetlerde fındığın çoğaltılması için Ordu ve Giresun'dan fidan getirilmesi için çalışma başlatılmış ve ayrıca Pazar şubesine 150 bin findık fidanı gönderilmesine başlanmıştır. Yerköy'de ağaç tohumları ekilerek elde edilecek fidanların dağıtımı için bir fidanlık tesisine karar verilmiş ve Midayiç Çiftliği'nden beş bin dönüm arazi alınması kararlaştırılmıştır. (Vakit, 2 Kanunuevvel/Aralık 1930; Milliyet, 2 Kanunuevvel/Aralık 1930)

Cemiyetin merkez heyeti üyelerinden Mithat Bey görevi nedeniyle Antalya'ya gidince yerine Ankara Valisi Nevzat (Tandoğan) Bey seçilmiştir. Merkez Heyetinden sonra Cemiyetin Genel Heyeti ise şöyle teşkil edilmiştir: Başkanlığa İzmir Milletvekili Rahmi Bey, Genel Sekreterliğe Hamdi Nafi Bey, azalıklara Edirne Milletvekili Faik Bey, Erzurum Milletvekili Aziz Bey, Konya Milletvekili Hamdi Bey, Mardin Milletvekili Ali Rıza Bey, Danıştay'dan Süreyya Bey, Orman İdaresinden Fahri Bey, muhasipliğe de Zeki Bey seçilmiştir (Cumhuriyet, 2 Kanunuevvel/Aralık 1930; Hakimiyeti Milliye, 3 Kanunuevvel/Aralık 1930).

Harf İnkılâbından sonra Türk diline uymayan yabancı kelimeleri atarak ve onların yerine Türkçe karşıllılarını bulup koymak isteği belirmiştir (Levend, 1960). Nitekim bu doğrultuda hareket eden Cemiyet de 1930 tarihli kongresinde Himayei Eşcar olan ismini Türkiye Ağaç

$5 \mathrm{Bu}$ programı hazırlayan uzmanların kimler olduğu ve programda nelerin yer aldığı bilgisi kayıtlarda yer almazken program nüshasının örneğine de ulaşılamamıştır.
Koruma Cemiyeti olarak değiştirmiştir. (Vakit, 2 Kanunuevvel/Aralık 1930; Hakimiyeti Milliye, 3 Kanunuevvel/ Aralık 1930; Arıkan, 1996) Bu isim değişikliğini Vakit gazetesi yazarı Sadri Etem ilginç bir anekdotla aktarmaktadır:

Ankara'dan gelen bir telgraf, Ankara'daki Himayei Eşçar Cemiyetinin bir içtimada adını değiştirmeğe karar verdiğini haber veriyor.

Ă̆aç koruma cemiyeti ve Ankara deyince aklıma ağaçlara dair bazı hatıralar geldi. Bundan sekiz sene evveldi. Ankara'da ara sıra ă̆aç bayramı yapılırdı. Herkes eline bir fidan alır. Bir de ibrik istasyon yolunda fidan dikerdi. Bir gün, belediye emir verdi. Her dükkâncı, dükkânın önüne bir fidan dikecektir diye. Dükkânların önüne birer fidan kondu..

Bir gece Yahudi mahallesindeki evime dönüyordum. Baktım sabahki gördüğüm fidanlar meydanda yok.. Saydım üç, dört, beş on... Tam altmış beş.. Hiçbir dükkânın önünde fidan yoktu.

Ertesi gün öğleye doğru aynı yollardan geçtim, dükkânların önünde kuru fidanlar sıra, sıra boy gösteriyor.

Dükkâncının birine sordum: Akşamlarl fidanlar ne oluyor? Adam yüzüme baktı, baktı:

- Efendi dedi, biz sabah dikiyoruz akşam alip götürüyorlar, tanrının günü fidan dikmekle uğraşacak değiliz ya.. Fakir fukara, odunsuz memlekette neylesin ă̆acı çekip götürür. Gündüzleri ağaçlara mukayyet oluyoruz, geceleri dükkânı kaparken fidanları içeri saklıyoruz, sabahlart gelince kepenkleri açtıktan sonra fidanları dikiyoruz. Dükkânın önünde ăgaç olmazsa, belediye bizlere ceza yazıyor.

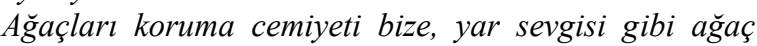
sevgisi öğretmeli adı gibi itiyatlarımızı da değiştirmelidir. (Vakit, 5 Kanunuevvel/Aralık 1930).

Diğer taraftan Cemiyetin isim değişikliğinin dilde sadeleşme karşıtları tarafindan tasvip edilmediği ve bazı eleştirilere konu olduğu da görülmektedir. ${ }^{6}$

Ağaç Koruma Cemiyetinin 1 Ocak 1931 tarihinde Dahiliye Vekaletine gönderdiği kayda göre idare heyeti şöyle şekillenmişti:

Başkan: Rahmi (Köken) Bey (İzmir Milletvekili)

Başkan Vekili: Faik (Kaltakkıran) Bey (Edirne Milletvekili)

\footnotetext{
${ }^{6}$ Örneğin Halil Nihat (Boztepe) Bey kalem aldığı 14 sayfalık ağaç kasidesinde isim değişikliğini hicvederek eleştirmektedir: Himayei Eşcar Cemiyeti Reisi Rahmi Beyfendiye Nasıldı ismi o cem'iyyetin, unuttum bak! Unutmasam da ne müşkül aruza uydurmak! Evet, himaye-i eşçar... geldi vezne hele! Düşeş denir buna lâkin... ya bir geleydi gele! Söz anlıyan beri gelsin, bakındı terkibe! O ismi cür'et eden kim bu yolda tertibe ? Bakındı kâtibimin şivei kitabetine! Bakındı medresenin küf kokan belâgatine! $\mathrm{Bu}$ yolda söylese Veysi ve Nerkisi söyler Vatanda kaç senedir inkılâp var monşer! Ağaç demek o kadar güç değil şecer yerine Nasıl ki taş demek imkânı var hacer yerine! Bilip esasını dernek diyorken ehli lûgat Bugünkü dilde de artık denir mi cem'iyyet? Mukabilinde diyorlar (himaye)nin (koruma)! Inanmiyan soruversin gidip te Erzuruma! Nedir himayei eşcar? Olur mu böyle isim? Bu eski şeyleri biz atmadık mı? Nerde fesim? ....... (Halil Nihat, 1931)
} 
Başkan Vekili: Aziz (Akyürek) Bey (Erzurum Milletvekili)

Üye: Ali Riza (Erten) Bey (Mardin Milletvekili)

Üye: Hamdi (Dikmen) Bey (Konya Milletvekili)

Üye: Süreyya (Özek) Bey (Danıştay Üyesi)

Üye: Fahrettin Bey (Orman Müdürlüğü Şube Müdürlerinden)

Genel Sekreter: Hamdi Nafi Bey

Muhasip: Zeki Bey (Ziraat Bankası İdare Meclisi Azasindan)

Aynı tarihlerdeki resmi kayıtlara göre Cemiyetin şubeleri ise Refahiye, Maraş, Çorum, Mecitözü, Osmancık, Alaca, İskilip, Sungurlu, Mersin, Tarsus, Kütahya, Emet, Tavşanlı, Uşak, Simav, Gediz, Tekirdağ, Şarköy, Saray, Çorlu, Hayrabolu, Malkara, Diyarbekir, Çanakkale, Isparta, Manisa, Kula, Soma, Konya, Kadıhan, Ereğli (Konya), Hadim, Sultaniye, Karaman, Akşehir, Seydişehir, Cihanbeyli, Beyşehir, Ermenak, Bozkır, Çumra, Ilgın, Kemah, Alâiye, Tuzluca, Göynük, Lice, Ergani, Silvan, Çermik, Kulp, Tosya, Bartın, Safranbolu, şeklindeydi (BCA, 1932).

\subsection{Cemiyetin kamuya yararlı bir dernek olmast}

Cemiyet Ankara'ya taşınır taşınmaz birtakım ayrıcalıklardan faydalanmaya başlarken ${ }^{7}$ hükümetin sağladığı ayrıcalık ve yardımlardan faydalanmak için de kamu yararına bir teşekkül olduğuna yönelik olarak Dahiliye, İktisat ve Ziraat vekaletlerine başvuruda bulunmuştur. Cemiyetin başvurusu, görülen eksiklikler nedeniyle Danıştay tarafından 16 Nisan 1931'de reddedilmiştir. $\mathrm{Bu}$ ret durumundan sonra eksikliklerini gideren Cemiyet, aynı yıl yeni bir başvuru daha yapmıştır. Bunun üzerine Danıstay gerekli incelemeleri yeniden başlatmıştır. Dönemin İktisat Vekili Mustafa Şeref (Özkan) Bey, Dahiliye Vekâletine yapılan araştırmaların sonucunu içeren şu yazıyı göndermiştir (BCA, 1932):

Umumi Merkezi Ankara'da bulunan Türkiye Himayei Eşcar Cemiyetinin maksat ve gayei teşekkülü halkta ă̆aç muhabbeti uyandırmak, genç dimağlarda ă̆aç sevgisinin esasl bir surette yerleșmesini te'min etmek, memleketin muhtelif mahallerinde fidanlıklar tesisi suretiyle fennî usuller dairesinde fidan yetiştirerek ahaliye tevzi etmek ve ăgaçtan mahrum olan mintıkaların ağaçlandırllmasına çalışmak ve ăgaç bakımı bilgisinin artırılmasını te'minden muktezi tedbirlere tevessül etmek olmasi ve bu suretle milli iktisadın bu sahadaki inkişafina ve halkın nef'ine hadim bulunmast itibariyle mezkur cemiyetin menafii umumiye hadim cemiyetler arasına sokulması muvafik olacă̆ mutalâasında bulunulduğunu ve mersül evrakın iadeten takdim kılındığını arz eylerim efendim (BCA, 1932).

Cemiyetin kamuya yararlı dernekler arasinda yer almasıyla genel bütçeden kendisine ödeme yapılmaya başlanmıştır. Nitekim Cemiyet, genel bütçeden 1940 yılında 3.000 lira (Ulus, 26 Mart 1940; Cumhuriyet, 21 Mayis 1940; Resmî Gazete, 25 Teşrinisani/Kasım 1944, Sayı:5866), 1941 yılında 3.000 lira (Resmî Gazete, 22 Nisan 1947, Sayı: 6589) 1942 yılında 3.000 lira (Cumhuriyet, 8 Nisan 1942), 1944 yılında 20.000 lira (Resmî Gazete, 25 Mayıs 1951, Sayı:7817), 1945 yılında 11.666 lira (TBMM Tutanak Dergisi, 23 Mayıs 1945) 1946 yılında 20.000 lira

\footnotetext{
7 Örneğin Evkaf İdaresi (Vakıflar Genel Müdürlüğü) 1930 yılında Cemiyete 500 liralık bir yardımda bulunmuştur (Aydın, 2006).
}

(TBMM Tutanak Dergisi, 2 Nisan 1952; Resmî Gazete, 11 Nisan 1952, Sayı:8083), 1947 yılında 10.000 lira (Resmî Gazete, 12 Mart 1954, Say1:8656), 1948 yılında 10.000 lira (Resmî Gazete, 13 Mart 1954, Sayı:8657), 1949 yılında 10.000 lira (Resmî Gazete, 28 Mayıs 1955, Sayı:9014), 1950 yılında 10.000 lira (TBMM Tutanak Dergisi, 17 Şubat 1950; Resmî Gazete, 30 Mayıs 1955, Say1:9015), 1951 yılında 10.000 lira (Resmî Gazete, 30 Mayıs 1955, Sayı:9015), 1953 yılında 5.000 (TBMM Tutanak Dergisi, 17 Ağustos 1956), 1954 yılında 5.000 lira (Resmî Gazete, 1 Mart 1954, Say1:8646) ve 1955 y1lında 5.000 lira (Resmî Gazete, 25 Eylül 1962, Sayı:11215) yardım almıştır. 1955 yılından sonraki yıllarda hazırlanan genel bütçelerde Cemiyete ayrılmış bir pay bulunmamaktadır.

Cemiyet, bütçe yardımları dışında 1943 yılında diğer devlet kurumları gibi devlet kırtasiye depolarından ürün alabilme ayrıcalığını da Cumhurbaşkanı İsmet İnönü’nün imzasıyla elde etmiştir (BCA, 1943).

\subsection{Cemiyetin programı ve nizamnameleri}

Cemiyetin Kemah'taki ilk kuruluşu sırasında Hamdi Nafi Bey 20 maddeden oluşan bir nizamname hazırlandığını ifade etmektedir. $\mathrm{Bu}$ kısa nizamnamede meyveli ve meyvesiz ağaçların çoğaltılması, ağaç sevgisinin telkin edilmesi üzerinde durulmuştur (Hamdi Nafi, 1929). 25 Mart 1929 tarihinde Kemah'da umumi kongresini toplayan cemiyet, daha kapsamlı bir -elli maddeden oluşannizamname neşretmiştir (Himayei Eşcar Cemiyeti Nizamnamei İdarisi, 1929).

Kemah'tan Ankara'ya taşındıktan sonra Başvekil İsmet (İnönü) Paşa'nın da fahri başkanlığını yaptığı Himayei Eşcar Cemiyeti amaç ve hedeflerini 5 Ocak 1930 tarihinde on maddelik bir mesai programı ile açıklamıştır. ${ }^{8} \mathrm{Bu}$ programda şunlar yer alıyordu: Halkta ağaç sevgisi uyandırmak için ağacın kıymeti, bakımı ve hastalıklarla nasıl mücadele edileceğine dair risale çıkarmak ve neşriyat yapmak. Okullar ve kışlalar ağaç sevgisini genç beyinlere en kuvvetli şekilde yerleştirecek mekanlar olduğundan Maarif Vekâleti (Milli Eğitim Bakanlığı) ve Milli Müdafaa Vekâleti (Milli Savunma Bakanlı̆̆ı) ile işbirliği yapmak. Memleketin ağaçtan en mahrum bölgelerinden başlayarak fidanlıklar tesis etmek ve fidan dağıtmak. İyi cins meyveler yetiştirmek için fidan aşıcılığını halka öğretmek, kurslar açmak ve aşı kalemleri dağıtmak. Tarıma zarar veren sel tahribatı çoğunlukla eğimli araziden akan sudan kaynaklandığından bu bölgelerin ağaçlandırılmasına özellikle itina göstermek. Ülkenin toprak ve iklim itibariyle meyveli ağaç yetiştirmeye çok müsait olmasına rağmen yetiştirilen meyvelerle dünya piyasasında rekabet edilemediğinden yüksek ve kaliteli verim alabilmek için halkı eğitecek uzmanlar yetiştirmek. Önceden planlayarak ağaç bayramları yapılmasına çalışmak (BCA, 1932).

Cemiyetin Ankara'ya taşınmasıyla ülke genelini kapsayan bir yapıya kavuşması sonucu yeni bir nizamnameye ihtiyaç duyulmuş ve hazırlanan bu nizamname Resmi Gazete'de yayınlanmıştır (Resmî Gazete, 29 Kanunusani/Ocak 1930, Sayı:1410; Türkiye Himayei Eşcar Cemiyeti Nizamnamei Esasi, 1930) 50 maddeden

\footnotetext{
${ }^{8}$ Programın başında İsmet Paşa'nın Cemiyetin fahri başkanı olduğu vurgusu mevcuttur. Fahri başkanlık durumunun tam olarak hangi tarihte İsmet Paşa tarafından kabul edildiği bilinmese de Cemiyetin Ankara'ya taşınır taşınmaz bu işlemi gerçekleştirdiği anlaşılmaktadır.
} 
oluşan nizamnameye göre Cemiyetin kuruluşu, çalışma prensipleri ve yapacağı işler şöyle anlatılmıştır:

Ağaçların çoğaltılmasına, iyi bakımına, cinslerinin ıslahına ve korunmasına yönelik olarak çalışmak üzere genel merkezi Ankara'da olmak üzere Himayei Eşcar Cemiyeti kurulmuştur (Madde 1).

Cemiyetin yapacağı görevler nizamnamesinin ikinci maddesinde ayrıntılı olarak ele alınmıştır: Meyveli Ağaçlar: a- Meyveli ağaçların artırılması için teşvik verilmesi, bŞubelerin bulunduğu alanlarda meyve ağaçlarının çoğaltılması için fidanlıklar tesisi ve yetişecek fidanların dağıtılması, c- Meyve ağaçlarının hastalıklardan ve zararlı böceklerden korunması, d- Meyve ağaçlarının cinslerinin 1slahi.

Meyvesiz Ağaçlar: a- Şube mıntıkalarındaki boş ve çıplak arazinin mahallerince tespit edilecek imkânlar neticesinde her sene ağaçlandırılması, b- Su kenarlarında kavak ve söğüt gibi çabuk yetişen ağaçların dikilmesini teşvik etmek, c- Ağaçlara zarar veren haşerata karşı yararlı kuşların himaye edilmesi ve çoğaltılmasına çalışmak.

Ağaç Sevgisi ve Yayın Faaliyetleri: a- Ağaçların korunması, çoğaltılması ve ıslahı için yayın yapılması, bOkullarda ve orduda ağaç sevgisi uyandırmak için ders verilmesi c- Hayvanların ağaçlara yaptı̆̆ 1 zararların önlenmesi d- Ağaçların odun olarak sarf edilmesinin önüne geçilmesi e- Ağaç bayramları yaptırılmak suretiyle ağaç sevgisinin arttırılması f- Ağaç ve mahsulleri için sergiler düzenlenmesi g- Mesleki bilginin artırılması.

Cemiyet Üyeliği: Her Türk cemiyete üye olabilirdi. Cemiyete üye olanlar her yıl 1-50 lira üye aidatı ödeyeceklerdir. Cemiyete büyük hizmeti geçenlere idare heyetinin kararıyla fahri üyelik unvanı verilir (Madde 3-5).

Merkezi Kongre: Cemiyetin merkezi kongresi iki senede bir defa Aralık ayının birinci günü cemiyet merkezinde toplanır. Merkezi kongre şehirlerdeki şubeler tarafından seçilen bir üye ile umumi idare heyetinden oluşur. Merkezi kongre üye salt çoğunluğu ile müzakereye başlar ve kongreyi umum idare heyeti başkanı açar. Merkezi kongrenin ilk toplantısında bir başkan, bir başkan vekili ve iki katip seçilir.

Merkezi Kongrenin Görevleri: Cemiyetin yaptığ 1 işlere dair genel bir rapor hazırlanması, cemiyetin önceki yıl bütçesinin incelenmesi ve bir sonraki bütçenin onaylanması, idare heyetince teklif olunan ve üyeler tarafindan teklif edilecek işlerin müzakere edilmesi, esas nizamnamenin tadilinine ilişkin olarak en az on üyenin imzalayacağ tekliflerin değerlendirilmesi, olağanüstü durumlar için toplantı talep edilmesi (Madde 8-13).

Umum İdare Heyeti: Cemiyetin bütün işlerinden sorumludur. Merkez kongrede seçilen dokuz üyeden oluşur. Bu üyelerin içerisinde bir orman, bir haşarat, bir meyvecilik, bir ağaç hastalıkları uzmanı olması şarttır. Heyete bir başkan, iki başkan vekili, bir genel sekreter ve bir de muhasip seçilecekti. Heyetin görevi; merkezi kongreyi toplamak, cemiyetin amaçlarını yaymaya çalışmak, cemiyetin bütün işlemlerini yönetmek, faaliyet raporları ve bütçeyi düzenlemekti. Heyet çoğunluk oyuyla karar verecekti. Başkan cemiyet adına yapılacak bütün işlerde nizamnameye göre hareket edecek ve cemiyeti temsil edecekti. Genel sekreter idari işlerde başkana karşı mesuldur, muhasip de mali işleri idare ve tetkik ile görevlidir (Madde 14-23).

Nizamnamenin 24-37. maddeleri şehirlerde ve kazalarda cemiyetin nasıl şubeleşeceğini, bu şubelerin kongrelerini nasıl yapacakları ayrıntılı bir şekilde ele alınmıştır. Bunun dışında yer alan 38-49. maddeler ise cemiyette görev yapacak memur ile müstahdemlere, cemiyetin bütçesine ve herhangi bir sınıflandırmaya tabi tutulmayan çeşitli maddelere ${ }^{9}$ yer verilmiştir (Ağaç Koruma Nizamnamesi, 1931).

Cemiyetin 1930 yılında hazırladığı nizamnamesi dokuz yıl yürürlükte kalmıştır. 1938 yılında yürürlüğe giren 3512 sayılı Cemiyetler Kanunu gereğince Cemiyet, 21 Haziran 1939 tarihinde yapmış olduğu genel kongresinde yeni nizamnamesini yayınlamıştır. 52 madddeden oluşan yeni nizamname bir öncekine göre daha kapsamlı hazırlanmıştır. Nizamnamede; cemiyetin amacı, yapılacak işler, ağaç sevgisi konusunda yapılacak neşriyat, cemiyete girme, çıkma şartları ve üyelik aidatı, cemiyetin teşkilatı ve merkez idare heyeti, şubelerin teşkilatı, cemiyet hesapları ve bu hesapların nasıl tetkik edileceği, cemiyetin taşınır ve taşınmaz mal varlığı ile gelirleri, cemiyetin feshi ve mallarının tasfiyesi gibi konulara ayrı başlıklar açılarak madde madde açıklanmıştır (Ulus, 24 Ekim 1939). Bununla birlikte özellikle nizamnamenin ikinci maddesi Cemiyetin siyasetle olan ilişkisini resmileştiriyordu. İlgili maddede Cemiyet Atatürk yolundan ayrılmayacağını ifade ederek kendi faaliyet şubelerinde Cumhuriyet Halk Partisi (CHP) prensiplerini tahakkuk ettirmeyi en esaslı gaye olarak kabul ve ilan ediyordu. Bu durum yönetici ve üyelerinin büyük çoğunluğu resmi olarak Cumhuriyet Halk Partili olan Cemiyet için malumu ilam etmekti. Ancak 1951 yılında bu nizamnamenin tüm maddeleri aynı haliyle basılırken ikinci maddede önemli bir değişikliğe gidilmiştir. İkinci Madde: Dernek Türk milletinin bir tek kurtuluş ve yükseliş yolu olan ve milleti mütemâdi itibar ve refah mevkiine yükseltmekte bulunan ATATÜRK rejimine bağll kalmay kabul ve ilan eder (Türkiye Ağaç Koruma Derneği Nizamnamesi, 1951) şeklinde düzenlenmiştir. Bu değişikliğe 1950 yılında yapılan genel seçimleri CHP'nin kaybetmesi ve Demokrat Partinin iktidara gelmesinin etki ettiği anlaşılmaktadır. Ayrıca bu değişiklik Cemiyetin kamu yararına bir dernek statüsünde bütçeden pay almaya devam etmek istemesiyle de ilintilidir.

\subsection{Cemiyetin faaliyetleri}

Cemiyetin 1929 yılında sadece 6 vilayet, 24 kaza ve 24 nahiyede şubesi bulunmaktaydı. 1931'e kadar bu sayı ciddi bir artış göstermiş ve Cemiyet, 41 vilayet, 430 kaza, 89 nahiye, 1020 köy ve ayrıca çeşitli köylerin birleştirilmesiyle oluşturulan 6 mıntıkaya yayılarak faaliyet sahasını genişletmiştir.

1929 yılında çeşitli meyve ağaçları için dağıtılan aşı miktarı 3300 civarındayken bu say1 1931'de 70360'a çıkarılmıştır. Aşılama konusunda özellikle sakız ağacının aşılanması ve Gaziantep'te yetiştirilen fistığın çoğaltılması için 7750 aşı dağıtılmıştır. Bu sayı 1929 'da 100 civarındadır.

Cemiyet 1931 yılında Türkiye genelinde ne cins ve miktarda aşı yapılacağı konusunda araştırma yaparak talepleri toplamıştır. Yapılan araştırma sonucuna göre talep edilen aşıları yetiştiren vilayetlerle temasa geçilerek bu

\footnotetext{
9 Nizamnamede müteferrik maddeler olarak tanımlanan bu kısımda; cemiyetin sahip olacağı emlâk, cemiyetin bulunduğu yerdeki en büyük mülki memurun teftişine her zaman açık olduğu, idare heyetlerinde bulunan şahısların üç toplantıya mazeretsiz katılmamaları halinde üyeliklerinin düşürüleceği gibi durumlara yer verilmiştir.
} 
aşıların dağıtımını organize etmeye çalışmıştır. İlk etapta 150 binden fazla aşı dağıtımı yapılmıştır (Hakimiyeti Milliye, 3 Mart 1931). Bununla birlikte yapılan dağıtımların eleştirildiği ve öneriler getirildiği gazete haberlerine de rastlamak mümkündür. Eleştiriler dağıtımda iklim koşullarının dikkate alınmadığı (örneğin Ankara), halkın dağıtılan fidanları ekmeden önce nasıl muhafaza edeceğini bilememesi ve uygun aşılamanın nasıl olacağı gibi konularda toplanmıştır. Ayrıca yapılacak aşılamayla ilgili olarak uygulanan tekniklerle ilgili sıkıntılar da dile getirilmiştir. $^{10}$

Cemiyet aşı temini konusunda vilayetlerle kurmuş olduğu temaslar neticesinde Amasya'dan elma, Edirne'den kiraz, şeftali, erik (Hakimiyeti Milliye, 24 Mart 1931), Kastamonu'dan da üryani ve misket eriği getirterek dağıtımına başlamıştır. Talep edenlerden her fidan için bir lira ücret istenmesi kararlaştırılmıștır (Hakimiyeti Milliye, 31 Mart 1931). Cemiyetin 1931 yılı mart ayına kadar dağıttığ1 aşı kalemi 200 bini geçmiş (Vakit, 23 Mart 1931) ve temmuz ayına kadar da 1.094 .859 ağaç diktiği bildirilmiştir (Hakimiyeti Milliye, 29 Temmuz 1931).

Artan talep dolayısıyla 1932 yılı şubat ayında Cemiyet, fidan isteyenlerden cins ve miktara ilişkin ön talep toplamaya başlamıştır (Hakimiyeti Milliye, 22 Şubat 1932). Aynı yılın ortalarına doğru Cemiyet Reisi İzmir Mebusu Rahmi Bey, gazetelere bir yıllık faaliyetleri hakkında demeç vermiştir. Buna göre 1.026.088 ağaç dikilmiştir. Bu sayının 508.842'si meyveli, 517,246's1 meyvesiz ağaçtır. Dikilen meyveli ağaçlar ve sayıları: Kayısı 84762, elma 89975, şeftali, 5860, armut 55701, ayva, 5500, erik, 50953, badem 3021, zerdali 9000, vişne 58600, kiraz 46411, zeytin 20000'dir. Meyvesiz ağaçlar ve sayıları: Akasya 157806, kavak 150791, gladiçya 8000, söğü 97000, servi 20937 , çınar 48612, çam 4560, ahlat 18327, sofora 3671 ve katalpa 6542. En çok ağaç sırasıyla Çanakkale, Bayazıt, Yozgat, Manisa, Erzincan ve Sivas'a dikilmiştir. Cemiyet meyveli ağaçların cinsini ıslah için 2250 Kayısı, 2050 elma, 3150 armut, 3100 kiraz, 3400 vişne, 1400 erik, 500 yapıncak, 200 zeytin, 150 kestane ve 100 adet de çekirdeksiz dut aş1 kalemini ücretsiz dağıtmıştır. Rahmi Bey, ülke topraklarında pek çok meyve yetiştirilse de bunların birçoğu ihracat için elverişli olmadığından özellikle ihracata yönelik çalışmaların yapılması gerektiğine dikkat çekmiştir (Hakimiyeti Milliye, 14 Mayıs 1932).

Cemiyetin 1934-1938 yılları arasındaki faaliyetleri detaylı olarak gazetelere yansımamıştır. Bu yıllarda daha çok gazetelerin reklam sayfalarında Cemiyetin meyve aşıları getirttiği ve bunların Cemiyetin merkezinden temin edilebileceği bildirilmektedir (Hakimiyeti Milliye, 11 Nisan 1934; Akşam, 22 Temmuz 1934; Ulus, 3 Nisan 1935, Akşam 16 Temmuz 1935; Ulus, 10 Mart 1936; Ulus, 14 Aralık 1937; Ulus, 18 Mart 1938; Ulus, 29 Mart 1938).

21 Haziran 1939'da genel kongresini toplayan Cemiyetin merkez idare heyeti şöyle teşkil edilmiştir: İzmir Mebusu Rahmi Köken, Mardin Mebusu Rıza Erten, Manisa Mebusu Yaşar Özey, Konya Mebusu Hamdi Dikmen, devlet

\footnotetext{
10 Türkiye'de genellikle aşılama geleneksel usulle, aşıların çamurla sıvanmasıyla yapılagelmiştir. Bu yöntem ile pek azı kalem tutmaktaydı. Bir diğer usul ise Avrupa macunlarıyla yapılan yöntemdi. Avrupa macunları ise kendi iklim koşullarına göre yapıldığından sıcak ya da rüzgarlı havalarda ya akmakta da ya da dökülmekteydi. Gazete, bu iki şeklin arasını bulmak amacıyla kil ve inek mayısını karıştırarak elde edilecek karışım ile işlem yapmayı önermiştir (Hakimiyeti Milliye, 8 Mart 1931).
}

şurası azasından Süreyya, Orman Genel Müdürü Fahri Bük, Ziraat Genel Müdürü Abidin Ege, orman mütehassısı Kemal ve ziraat vekaleti şube müdür muavinlerinden Şevki. Aynı kongrede Cemiyet nizamnamesini değiştirmiş ve Ankara civarında 100 bin meyve aşısı yapıldığı duyurmuştur (Ulus, 22 Haziran 1939; Akşam 22 Haziran 1939).

1940 yılında Cemiyet 123 bin yabani ağaç aşılamıştır. $\mathrm{Bu}$ ağaçlardan 68.600'ü Ankara'da 55.000'i diğer vilayetlerdedir (Ulus, 15 Mayıs 1940; Vakit, 16 Mayıs 1940).

Cemiyet, 1941 yılı içerisinde 92 köyde 189.000 ağaç aşılamıştır. Bunun dışında 10500 iyi cins elma ve armut fidanları adet 18 vilayete gönderilmiştir (Ulus, 15 Nisan 1942).

Cemiyet, 1940-1942 yıllarında Ankara ve civarındaki bölge halkına ücretsiz meyve aşısı kalemi dağıtmaya devam ettiğini ve bunun için merkez şube adresine başvurulması gerektiğini gazeteler aracılığıyla duyurmaya çalışmıştır. (Ulus, 7 Şubat 1940, Ulus, 17 Mart 1942)

1942 yılının başında Cemiyet, 12 vilayetin 22 kaza ve köylerinde aşı işleri için 89 aşıcı çalıştırmaktaydı. Aşılar yaylalarda yer alan ahlat ağaçlarına Ankara armudu, yabani elmanın olduğu bölgelerde Amasya elması, Siirt, Urfa, Diyarbakır, Malatya, Mardin, Elazığ, Konya, İzmir, Balıkesir, Eskişehir, Erzincan ve Çanakkale vilayetlerinde Antep fistığı aşılanması şeklinde planlanmıştır. Ayrıca kalem aşısının bir buçuk ay daha devam edeceği ve ardından ahlat, elma ve sakız ağaçları üzerinde göz aşısına başlanacağı bildirilmiştir (Ulus, 15 Nisan 1942). Bu çalışmalar için Ankara'daki bağ ve bahçelerde bulunan ağaçlara yönelik yapılacak göz aşıları için Cemiyete başvurarak ücretsiz aşıcı ustalarının gönderileceği de halka duyurulmuştur (Ulus, 25 Ağustos 1942; Uluöz, 1945).

Cemiyet, 16 Aralı 1942 genel kongresini toplayarak faaliyetlerini basın ile paylaşmıştır. Cemiyetin basına verdiği faaliyet raporuna göre son üç yıl içerisinde 15 vilayetin 302 köyünde 615.000 ağaç aşılanmış, çeşitli bölgelerde 40.000 fidan ile 47.500 aşı kalemi dağıtılmıştır. Aynı kongrede cemiyet merkez teşkilatında önemli değişiklikler de gerçekleşmiştir. Cemiyet reisliğine Manisa Mebusu Yaşar Özey, ikinci reisliğe Orman Genel Müdürü Fahri Bük, azalıklara İzmir Mebusu Rahmi Köken, Mardin Mebusu Hamdi Dikmen, Ziraat Bakanlığı Müsteşarı Abidin Ege, Devlet Şurası Azası Süreyya Özek, Prof. Ali Kemal Yiğitoğlu, muhasip azalığa da Ziraat Bakanlığ s şube müdürlerinden Hikmet Oklar seçilmiştir (Ulus, 16 Aralık 1942).

Cemiyet, 1943 yılında isteyenlere ücretsiz göz aşısı yapacağı bilgisini vererek -telefon hattının yeni çekilmesinden olsa gerek- ilk defa 1002 olan telefon numarasını da paylaşmıştır (Ulus, 17 Haziran 1943). Aynı yıl Malatya'ya gönderilen aşıcı ustalar sayesinde 4 bin adet yabani sakız ağacına 12.900 aşı tatbik edildiği ve bu aşıların \%95 oranında tuttuğu bilgisi verilmiştir (Ulus, 8 Ağustos 1943).

1944 yılında Cemiyet, Ankara, Çankırı, Konya, Denizli, Eskişehir, Antalya, Burdur, İzmir, Manisa, Balıkesir vilayetlerinin çeşitli köylerine yabani ağaçları aşı ile ıslah çalışmalarını sürdürdüğünü, birkaç senedir üzerinde dikkatle çalışılan Antep fistığı aşısına da göz aşısı mevsiminde geniş ölçüde devam edilmek üzere tertibat aldığını ifade etmiştir. Köylere gönderilen aşıcı ustaları bir yandan köylünün ağaçlarını aşılarken diğer taraftan da onlara ağaç bakımı ile 
fenni ve pratik aşıcılığı öğrettiğini duyurmuştur (Ulus, 22 Nisan 1944).

1945 y1lında Cemiyet, eskiden olduğu gibi yurdun çeşitli bölgelerinden meyve aşıları getirttiğini ve kendisine başvurulması halinde bu kalemleri meraklı bahçe sahiplerine ücretsiz dağıtacağını bildirmiştir. $\mathrm{Bu}$ arada Cemiyet merkez adresinde değişiklik yaparak Hükümet Caddesi Dr. Lütfi Hikmet Apartmanı birinci katından (Ulus, 24 Ekim 1939; Ulus, 7 Şubat 1940) Anafartalar Karakolu karşısına taşınmıştır (Ulus, 21 Mart 1945).

1946 yılında Cemiyet, son üç yıldaki faaliyetlerini açıkladığı raporunda; 24 vilayetin 649 köyünde 813.500 yabani ağacın aşılatıldığını, 47 ilçede 70.000 meyveli ve meyvesiz fidanla 50.000 iyi cins aşı kaleminin çeşitli bölgelere parasız dağıtıldığını bildirmiştir (Ulus, 27 Ocak 1946). Cemiyet Menemen'deki Kubilay Anıtı'nın çevresi ve Dumlupınar Zafer Anıtı'nın ağaçlandırılması için teşebbüslere girişmiştir. Köylerde ağaç aşısı ve ağaç bakımı tekniğinin yayılmasını sağlamak için kurslar açılmış, 600'den fazla aşıcı yetiştirilmiştir. Cemiyet 1940-1946 yılları arasında 1.430 .000 ağaç aşılatmış ve köylülere 122.000 fazla ücretsiz fidan dağıtmıştır (Ulus, 30 Ocak 1946).

Cemiyet yapmış olduğu saha çalışmalarının yanı sıra nizamnamesinde de yer aldığı üzere yayın faaliyetlerinde bulunmuştur. Ağaç aşıcılığının fenni noktasında Aşıcılık adında 700 sayfalık bir eser ${ }^{11}$ ülkenin her tarafına dağıtılmıştır (Hakimiyeti Milliye, 23 Mart 1930; Vakit, 2 Kânunuevvel/Aralık 1930). Ayrıca İsfendiyar Esat (Kadester)'ın çıkardığı Gübre ve Ağaç isimli kitabın Cemiyete müracaat edilerek temin edilebileceği bildirilmiştir (Akşam, 15 Teşrinievvel/Ekim 1933).

\subsubsection{Cemiyet tarafindan ülke genelinde düzenlenen ăgaç bayramlart}

Ağaç Bayramı, Batı'da ağaç festivali, ağaç günü, ağaç şenlikleri gibi değişik isimlerle kutlanmıştır. İlk olarak 1899'da Fransa'da Ağaç Bayramı ismiyle kutlanmaya başlayan bayram kısa sürede İtalya, İspanya, Almanya, Rusya, İsveç, Avusturya-Macaristan, İsviçre, Portekiz ve Japonya'da da kutlanmaya başlanmıştır (Kılıç, 2020). Bu ülkelerin önde gelen yöneticileri de bu bayrama katılarak ağaç dikimini özendirmeye çalışmıştır.

Ağaç Bayramı Osmanlı Devleti'nde ise 1910'lu yıllardan itibaren kutlanmaya başlanmıştır. Ancak bu bayram ile ilgili düşünce ve uygulamaların istikrarlı bir şekilde sürdürülmesi dönemin savaş koşulları dolayısıyla pek mümkün olmamıştır (Akyüz ve Öztürk, 2002). Mondros Mütarekesi'nden sonra ortaya çıkan işgal koşullarına rağmen Ağaç Bayramları bölgesel de olsa kutlanmaya çalışılmıştır. Bu kapsamda Ağaç Bayramı etkinliklerinin Kazım Karabekir Paşa tarafindan Erzurum ve Kars civarında organize edildiği, kutlamalara oldukça önem verildiği, özelikle çocuklara ağaç sevgisi kazandırmak için tüm gün etkinlikler yapıldığı anlaşılmaktadır (Karabekir, 2009).

Misak-1 İktisadi Esaslarının kararlaştırıldığı İzmir İktisat Kongresinde (17 Şubat-4 Mart 1923) de Ağaç Bayramı ile ilgili kararlar da alınmıştır. Kongrede Misak-1 İktisadi

\footnotetext{
${ }^{11}$ Charles Baltet tarafindan kaleme alınan kitap, Cemiyet Azası Edirne Milletvekili Faik (Kaltakkıran) Bey tarafından tercüme edilmiştir. Ayrıntılı bilgi için bkz. Baltet, 1930.
}

Esasları başı̆̆ğ altında Türkiye halkının ormanları evladı gibi sevdiğinden ağaç bayramları yaptığı, Orman Meselesi başlığı altında da memleketin her tarafında mevsime göre Ağaç Bayramı yapılması, öğrencilerin ve ahalinin bu bayram gününde birer ağaç dikmeye mecbur tutulmaları kabul edilmiştir (İBB, 2004). Alınan kararlar doğrultusunda tüm yurtta ağaç bayramları düzenlenmiştir (Kılıç, 2020).

Birbirinden bağımsız ve yerel düzeyde yapılan Ağaç Bayramlarının belirli bir planlamayla ülke genelinde yapılması için Himaye-i Eşcar Cemiyeti 20 maddelik bir talimatname yayınlamıştır. $\mathrm{Bu}$ talimatnamede Ağaç Bayramı'nın her yıl düzenleneceği, bayramların özellikle herkesin katılabilmesi için tatil günlerine denk getirilmesi, ağaç dikim alanlarının mümkün olduğunca suya yakın bölgelerden seçilmesi, ağaç dikilecek yerlerin önceden tespit edilerek gerekli hazırlıkların yapılması (çukur kazılması, fidan miktarının tespiti gibi), dikim yapılacak fidanların bölge iklimine uygun seçilmesi (talimatta hangi bölgeler için hangi tercihlerin yapılması gerektiği yazılmıştır), dikimin nasıl yapılacağının uzmanlar tarafından uygulamalı gösterilmesi, dikim yapılan bölgenin insan ve hayvan tecavüzünden korunması için çit, duvar gibi manialarla çevrilmesi, mümkün ise bir bekçi istihdam edilmesi, ağaçlanan bölgenin bütün ihtiyacını temin için bir cemiyet üyesinin sorumlu olarak görevlendirilmesi, halka ağaç sevgisinin telkin edilmesi ve ağaç bakımı konusunda halkın eğitilmesi, bu çalışmaları yaparken gerekli neşriyatın ve konferansların verilmesi, yapılan faaliyetlerin cemiyete rapor ile bildirilmesi yer almaktaydı. Cemiyet şubeleri ağaç bayramlarından bu programı tatbik ederek mahallin en büyük mülkiye memurunun başkanlığında çalışacaktı (Resmî Gazete, 20 Teşrinisani/Kasım 1930, Sayı:1652; Ağaç Bayramı Talimatnamesi, 1930).

Cemiyet, 1931 yılından itibaren Ağaç Bayramı kutlamalarının pek çok il ve ilçede öncülüğünü yapmıştır. Bayram kapsamında 1931 yılında 154.580 ağaç dikilmiştir. Aynı yılın ilkbaharında da Cemiyet merkezi ve şubeleri aracılığıyla 1.094.859 ağaç diktirmiştir. Ağaç Koruma Cemiyetinin yanı sıra 1932 yılında kurulan Halkevleri ${ }^{12}$ de bulundukları bölgelerde Ağaç Bayramlarını organize etmiştir. ${ }^{13}$ Halkevlerinin köycülük şubesi farklı görevlerin yanı sıra köylerin ağaçlandırılması, meyveli ağaç yetiştirilmesinin özendirilmesi, köylülere eğitim verilmesi gibi görevleri de üstlenmiştir (Emgili, 2021). Bu durum Türkiye Ağaç Koruma Cemiyetiyle Halkevi köycülük şubesi arasında yapılan faaliyetlerde bir takım paralellikler olduğunu göstermektedir.

Ağaç Bayramları kapsamında yapılan etkinliklerin İkinci Dünya Savaşı ve sonrası dönemde sekteye uğradığı görülmektedir. Nitekim dünyanın çeşitli bölgelerinde uçakla tohum serpmek suretiyle ağaç dikimi yapıldığına yönelik bir

\footnotetext{
${ }^{12}$ Halkevleri vatandaşların ilgisini çekmek ve vatandaşların kendilerine bir faaliyet alanı bulabilmeleri için dokuz şube üzerine teşkil edilmiştir. Bunlar; dil ve edebiyat şubesi, güzel sanatlar şubesi, temsil şubesi, spor şubesi, sosyal yardım şubesi, halk dershanesi ve kurslar şubesi, kütüphane ve yayın şubesi, köycülük şubesi ile tarih ve müze şubesi şeklindedir (Özdemir ve Aktaş, 2011).

13 Ağaç Bayramları ile ilgili olarak gazetelerde değişik yıllarda çok sayıda haber bulunmaktadır. Özellikle şehrin mülki erkanı bu törenlere katıldığından her yıl çeşitli bölgelerde yapılan kutlamalar gazetelerde detaylı olarak yer almıştır. Haberlerde bayramlar ön planda olup bayramı Halkevinin mi yoksa Cemiyetin mi düzenlediğine dair bilgiler genellikle yer almamaktadır. Bu nedenle tüm Ağaç Bayramlarını Cemiyetin düzenlediğini söylemek mümkün değildir. Ağaç Bayramları konusunda ayrıntılı bilgi için bkz. Kılıç, 2020.
} 
gazete haberi şöyle devam etmekteydi: Biz işin tayyaresinden ve romantiğinden vazgeçtik, şu Istanbul şehrinin âmmeye tahsis edilmiş en göze görünür yerlerine üç, beş yüz ăgaç diktiren ă̆aç bayramlarına devam etsek bari ve ormanlarımızı tahrip etmesek (Akşam, 24 Temmuz 1949).

\subsection{Cemiyete dair son bilgiler}

Cemiyetin 1950 yılından sonra ne tür çalışmalar yürüttüğü ve idari kadrosunda değişiklik olup olmadığı gibi durumlar net olarak belli değildir. Özellikle 14 Mayıs 1950'de yapılan genel seçimlerle Demokrat Partinin iktidara gelmiş olmasiyla mevcut siyasi koşullarda önemli bir değişim olmuştur. Bu değişimden yola çıkarak Cemiyetin mevcut CHP bağlantılı haliyle yeni hükümetin gözünde eski pozisyonunu muhafaza ettiğini ya da aynı desteği alabildiğini söylemek zordur. Yine DP'nin iktidarı gelmesiyle Cemiyete genel bütçeden yapılan yardım miktarının önceki yıllara nazaran yarı yarıya azaltıldığ görülmektedir. Tüm bunlarla birlikte Cemiyete ait son kayıt 1955 yılına aittir. Bu kayıt 1962 yılında yapılan, bulunduğu tarihten yedi yıl öncesine ait olan, 1955 Malî Y1lı Kesin Hesap Kanunu'nda Cemiyete 5.000 lira ödeme yapılmasına yöneliktir (Resmî Gazete, 25 Eylül 1962, Sayı:11215). 1950-1955 ve sonraki yıllarda tüm araştırmalara rağmen Cemiyetle ilgili başka bir kayda ulaşılamamıştır.

\section{Sonuç}

Himayei Eşcar adıyla 1928 yılında kurulan ve daha sonra dilde sadeleşme hareketi kapsamında Türkiye Ağaç Koruma Cemiyeti adını alan Cemiyet cumhuriyet dönemi çevreci yapılara verilebilecek ilk örneklerdendir.

Genel olarak cemiyetlerin/derneklerin/sivil toplum kuruluşlarının amacı bir takım ekonomik ve sosyal kazanımlar elde etmek olduğu gibi, kendi mesleki alanlarını ilgilendiren konularda da devleti yönetenlere birtakım politikalar önererek yönetim sürecine bir yerden dahil olma durumunu içermektedir (Erdal ve Aydın, 2017). Buna karşın Türkiye Ağaç Koruma Cemiyetinin mevcut yapısıyla yani başkan ve üyelerinin milletvekili/üst düzey devlet görevlisi olduğu düşünüldüğünde bahse konu durumlar dışında özellikler gösterdiği açıktır.

Cemiyetin yapmış olduğu faaliyetler değerlendirildiğinde ülke genelinin ağaçlandırılması için Ağaç Bayramları düzenlenmesi bir tarafa bırakılacak olursa özellikle meyve yetiştiriciliği ve ihracatı konusu ön plana çıkmaktadır. Uygulanmak istenen politikalarla geleneksel yöntemlerle yapılan meyveciliğin değiştirilmesi, uluslararası piyasada rekabet edebilmek için kalite ve verimin artırılması hedeflenmiştir. Yine ülke genelindeki iklim ve toprak koşulları dikkate alındığında bir ürünün bir bölgede değil de farklı farklı noktalarda yetiştirilmesi için çaba harcandığ görülmektedir. Bununla birlikte Cemiyetin yapmış olduğu meyve 1slah çalışmalarının günümüze etkisinin ne kadar olduğu bilin(e)memektedir. Benzer şekilde ağaçlandırılan bölgelerin de günümüze ulaşıp ulaşmadığı konusu net değildir.

Cumhuriyetin kuruluşundan itibaren her alanda olduğu gibi ağaç yetiştirme konusunda da uzman kişilere duyulan ihtiyaç had safhadadır. Cemiyet bunu aşmak için kendisine başvuranlara ücretsiz destek vermeyi taahhüt etmiş olsa da elindeki uzman sayısının ne düzeyde olduğu ve çalışmalardan ne gibi sonuçlar alındığına dair bir bilgi bulunmamaktadır. Benzer şekilde yayın yoluyla da halkın eğitileceği ifade edilmiş olsa da günümüze ulaşmış bir-iki çalışma dışında kayda tesadüf edilememiştir.

Cemiyetin 1940 yılı sonrasındaki faaliyetlerinin basında giderek daha az yer bulduğu görülmektedir. $\mathrm{Bu}$ duruma İkinci Dünya Savaşı'nın ve savaş sonrası yaşanan gelişmelerin tesir ettiği söylenebilir. Ayrıca dönem itibariyle özellikle ülkenin ekonomik anlamda ciddi sorunlarla karşı karşıya olması kamuya yararlı derneklere ayrılan bütçenin de azaltılması ya da kesilmesine yol açmıştır. Yaşanan gelişmeler haliyle Cemiyetin de hareket sahasını daraltmış ve faaliyetlerinin azalmasına yol açmıştır. Yine kendisiyle benzer misyonları bulunan Halkevleri köycülük şubelerinin faaliyetleri de Cemiyetin geri plana düşmesinde etkili olmuştur. Tüm bunlara 1950 yılında gerçekleşen genel seçimler neticesinde yaşanan iktidar değişikliği de eklenince idareyi eline alan DP'nin de Cemiyet üye ve azalarının CHP ile olan göbek bağını görmezden gelmesi beklenemezdi. Ayrıca Cemiyet bünyesinde yer alan milletvekilleri de seçim sonrası parlamentoya girememişlerdi. Bu dönem Cemiyet adına göze çarpan önemli bir değişiklik de 1939'da çıkardığı nizamnamesini yeniden 1951'de yayınlarken nizamnamede yer alan CHP ile ilgili kısımların metinden çıkartılmasıdır. Seçim sonrası siyasi desteğini kaybeden Cemiyetin nizamnamesini de yeni siyasi şartlara göre tadil etmesi gücünün azaldığına işaret etmektedir. $\mathrm{Bu}$ siyasi gelişmelere ilaveten Cemiyete verilen ekonomik destek de azalmıştır. Nitekim 1950-1955 yılları arasında Cemiyetin bütçeden aldığ1 payın \%50 düştügü görülmektedir. Tüm veriler ışığında 1950-1955 yılları arasında genel bütçeden ayrılan pay dolayısıyla faaliyetlerine devam ettiği anlaşılan Cemiyetin bahse konu yıllardaki faaliyetleri ve sonraki yıllardaki akıbetinin ne olduğuna dair bir bilgiye tesadüf edilememiştir.

\section{Kaynaklar}

Ağaç Bayramı Talimatnamesi, 1930. Türk Ocakları Merkez Heyeti Matbaas1.

Ağaç Koruma Nizamnamesi, 1931. Dördüncü Tabı, Yeni Gün Matbaas1, Ankara.

Akşam Gazetesi, 4 Kanunuevvel/Aralık 1930.

Akşam Gazetesi, 15 Teşrinievvel/Ekim 1933.

Akşam Gazetesi, 22 Temmuz 1934

Akşam Gazetesi, 16 Temmuz 1935.

Akşam Gazetesi, 22 Haziran 1939.

Akşam Gazetesi, 24 Temmuz 1949.

Akyüz, Y., Öztürk, F., 2002. İlk ağaç bayramı girişimi. Tarih ve Toplum, 38: 225-226

Arıkan, Z., 1996. Dilde sadeleşme akımı ve köylü gazetesi. Kebikeç, 4: 141

Arslan, Z., 2010. Osmanlı'da Toplumsal Örgütlenmeye Geçiş ve Cemiyetleşme Faaliyetleri. Türk Yurdu, 99(276): 59.

Aydın, D., 2006. Cumhuriyet dönemi vakıfları tarihi bir bakış ve vergi muafiyetine sahip vakıfların mali krizi, Türkiye'de Hayırseverlik: Vatandaşlar, Vakıflar ve Sosyal Adalet, Editörler: Zincir R., Bikmen F., TÜSEV, İstanbul, s.58.

Baltet, C., 1930. Așıcıllk. Mütercimi: Fayık, Resmi Gazete Matbaas1, İstanbul.

BCA, 1921. Türkiye Cumhuriyeti Cumhurbaşkanlığı Devlet Arşivleri Başkanlığ 1 Cumhuriyet Arşivi, 6 Ocak 1921, 185 275-1.

BCA, 1932, Türkiye Cumhuriyeti Cumhurbaşkanlı̆̆ Arşivleri Başkanlığı Cumhuriyet Arşivi, 12 Ocak 1932, 80526-10. 
BCA, 1943. Türkiye Cumhuriyeti Cumhurbaskanlığı Devlet Arşivleri Başkanlığ Cumhuriyet Arşivi, 26 Temmuz 1943, 102-57-12.

Benli, M., 2014. Türkiye Cumhuriyeti'nde Ormanc1lı Politikaları (1923-1946). Yüksek lisans tezi, Fatih Sultan Mehmet Vakıf Üniversitesi Sosyal Bilimler Enstitüsü, İstanbul, s.45.

Cumhuriyet Gazetesi, 2 Kanunuevvel/Aralık 1930.

Cumhuriyet Gazetesi, 21 Mayıs 1940.

Cumhuriyet Gazetesi, 8 Nisan 1942.

Emgili, F., 2021. Halkevlerinin köy ve köycülük faaliyetleri. Tarih ve Günce, S.8: 209.

Erdal S., Aydın S., 2017. Sivil toplum bağlamında 11.meşrutiyet dönemi'nde (1908-1918) öğretmen cemiyetleri ve terakki-i maârif ve ittihâd-1 muallimin cemiyeti. Atatürk Üniversitesi Türkiyat Araștırmaları Enstitüsü Dergisi, 58: 409-426.

Gönüllü, A. R., 2008. Meşrutiyet'ten Cumhuriyet'e Alanya (19081938), Atatürk Araştırma Merkezi, Ankara, s.125.

Gülen, İ., - Özdönmez, M., 1981. Türkiye'de orman ve ormancılık. İstanbul Üniversitesi Orman Fakültesi Dergisi, 31: 2-6.

Gümüss, C., 2014. Osmanlıdan günümüze ormancılık politikalarının ormanc1lık örgütlenmesi üzerine etkileri ve güncel sorunlar. II. Ulusal Akdeniz Orman ve Çevre Sempozyumu, s.481.

Gümüş, C., 2018. Türk Orman Devrimi, Türkiye Ormancilar Derneği, Ankara, s.148.

Hakimiyeti Milliye Gazetesi, 2 Aralık 1929.

Hakimiyeti Milliye Gazetesi, 25 Teşrinievvel/Ekim 1930.

Hakimiyeti Milliye Gazetesi, 7 Kanunisani/Ocak 1930.

Hakimiyeti Milliye Gazetesi, 6 Şubat 1930.

Hakimiyeti Milliye Gazetesi, 12 Şubat 1930.

Hakimiyeti Milliye Gazetesi, 23 Mart 1930.

Hakimiyeti Milliye Gazetesi, 5 Mayıs 1930

Hakimiyeti Milliye Gazetesi, 3 Kanunuevvel/Aralık 1930.

Hakimiyeti Milliye Gazetesi, 3 Mart 1931.

Hakimiyeti Milliye Gazetesi, 8 Mart 1931

Hakimiyeti Milliye Gazetesi, 24 Mart 1931.

Hakimiyeti Milliye Gazetesi, 31 Mart 1931.

Hakimiyeti Milliye Gazetesi, 29 Temmuz 1931.

Hakimiyeti Milliye Gazetesi, 22 Şubat 1932.

Hakimiyeti Milliye Gazetesi, 14 Mayıs 1932.

Hakimiyeti Milliye Gazetesi, 11 Nisan 1934

Halil Nihat, 1931. Ağaç kasidesi, Agâh-Sabri Kitaphanesi, İstanbul, s.3.

Hamdi Nafi, 1929. Ağacın kıymetini bilelim. Orman ve Av, 14: 23.

Hanioğlu, Ş.M., 1993. Cemiyet. Türkiye Diyanet Vakfı İslâm Ansiklopedisi, C.7, s.331.

Himayei Eşcar Cemiyeti Nizamnamei İdarisi, 1929. Orman ve Av, 14: 12-16.

İBB, 2004. İzmir İktisat Kongresi 17 Şubat-4 Mart 1923 (2004), İzmir Büyükșehir Belediyesi Kent Kitaplığı, Stil Matbaacılık A.Ş., İzmir, s.11-15.

İctihad, 15 Temmuz 1930. No: 301

Karabekir, K., 2009. Günlükler (1906-1948). Yapı Kredi Yayınları, İstanbul, s.674, 740, 885.

K1lıç, E., 2020. Osmanlı'dan Türkiye Cumhuriyeti'ne ağaç bayramları, Yüksek lisans tezi, Bursa Teknik Üniversitesi Fen Bilimleri Enstitüsü, Bursa.

Kutluk, H., 1936. Ağaç koruma cemiyeti ve isteğimiz. Verim, 9-10: 13.
Levend, A.S., 1960. Türk Dilinde Gelissme ve Sadeleșme Evreleri. Türk Tarih Kurumu Basımevi, Ankara, s.406.

Milliyet, 2 Kanunuevvel/Aralık 1930

Özdemir, Y., Aktaş, E., 2011. Halkevleri (1932'den 1951'e). Atatürk Üniversitesi Türkiyat Araştırmaları Enstitüsü Dergisi, 45: 235-262.

Resmî Gazete, 29 Kanunusani/Ocak 1930, Say1:1410.

Resmî Gazete, 20 Teşrinisani/Kasım 1930, Sayı:1652.

Resmî Gazete, 25 Teşrinisani/Kasım 1944, Sayı:5866.

Resmî Gazete, 22 Nisan 1947, Say1: 6589.

Resmî Gazete, 25 Mayıs 1951, Sayı:7817.

Resmî Gazete, 11 Nisan 1952, Say1:8083.

Resmî Gazete, 1 Mart 1954, Sayı:8646.

Resmî Gazete, 12 Mart 1954, Sayı:8656.

Resmî Gazete, 13 Mart 1954, Sayı:8657.

Resmî Gazete, 28 Mayıs 1955, Say1:9014.

Resmî Gazete, 30 Mayıs 1955, Say1:9015.

Resmî Gazete, 25 Eylül 1962, Say1:11215.

TBMM Tutanak Dergisi, 23 Mayıs 1945. Dönem: 7, Cilt: 17, 60. Birleşim, s.295.

TBMM Tutanak Dergisi, 17 Şubat 1950. Dönem: 8, Cilt: 24, 49. Birleşim, s.771.

TBMM Tutanak Dergisi, 2 Nisan 1952. Dönem: 9, Cilt: 14, 56. Birleşim, s.33.

TBMM Tutanak Dergisi, 17 Ağustos 1956. Devre: 10, Cilt:18, 92. İnikat, s.57.

Toprak, Z., 1985. 1909 cemiyetler kanunu. Tanzimat'tan Cumhuriyet'e Türkiye Ansiklopedisi, C.1, s.206.

Türkiye Ağaç Koruma Derneği Nizamnamesi, 1951. Ankara Üniversitesi Basımevi.

Türkiye Himayei Eşcar Cemiyeti Nizamnamei Esasi, 1930. Ankara. Uluöz, M., 1945. Türkiye ağaç koruma cemiyeti. Bakış, 1: 85-86.

Ulus Gazetesi, 3 Nisan 1935.

Ulus Gazetesi, 10 Mart 1936.

Ulus Gazetesi, 14 Aralık 1937.

Ulus Gazetesi, 18 Mart 1938.

Ulus Gazetesi, 29 Mart 1938.

Ulus Gazetesi, 22 Haziran 1939.

Ulus Gazetesi, 24 Ekim 1939.

Ulus Gazetesi, 24 Ekim 1939.

Ulus Gazetesi, 7 Şubat 1940.

Ulus Gazetesi, 26 Mart 1940.

Ulus Gazetesi, 15 Mayıs 1940.

Ulus Gazetesi, 17 Mart 1942.

Ulus Gazetesi, 21 Mart 1942.

Ulus Gazetesi, 15 Nisan 1942.

Ulus Gazetesi, 25 Ağustos 1942.

Ulus Gazetesi, 16 Aralık 1942.

Ulus Gazetesi, 17 Haziran 1943.

Ulus Gazetesi, 8 Ağustos 1943.

Ulus Gazetesi, 22 Nisan 1944.

Ulus Gazetesi, 21 Mart 1945.

Ulus Gazetesi, 27 Ocak 1946.

Ulus Gazetesi, 30 Ocak 1946.

Vakit, 2 Kanunuevvel/Aralık 1930.

Vakit Gazetesi, 5 Kanunuevvel/Aralık 1930.

Vakit Gazetesi, 23 Mart 1931.

Vakit Gazetesi, 16 Mayıs 1940. 


\section{Ekler}

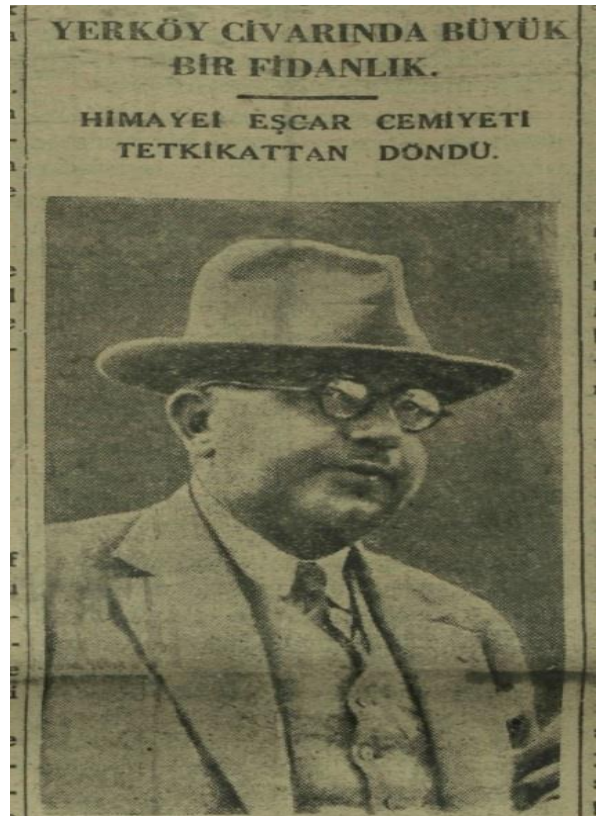

Türkiye Ağaç Koruma Cemiyeti Reislerinden Edirne Mebusu Rahmi Bey (Hakimiyeti Milliye, 12 Şubat 1930)

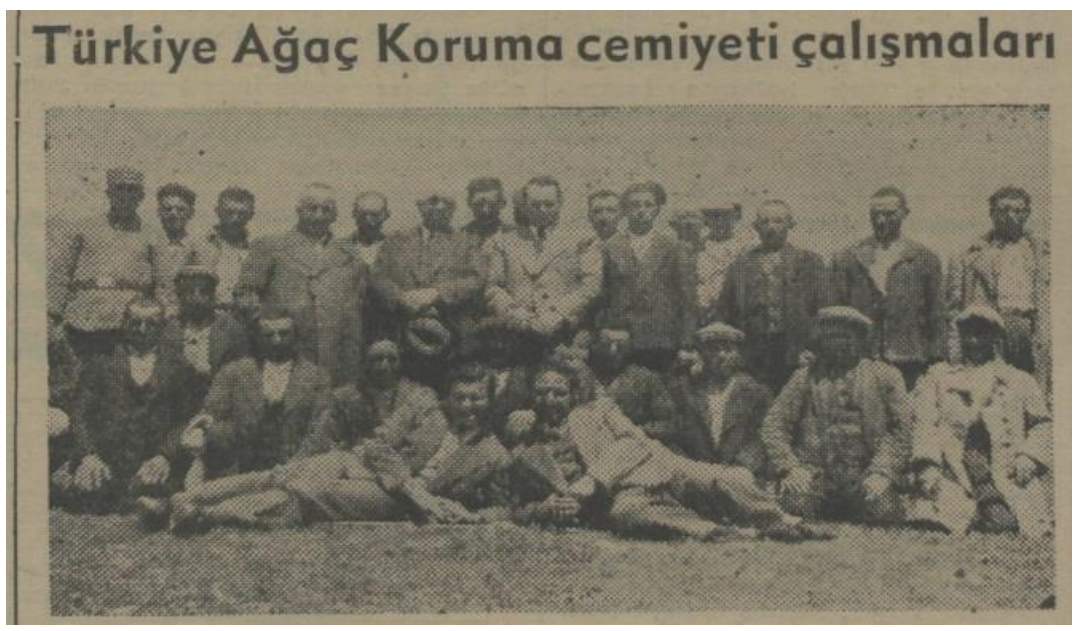

Türkiye Ağaç Koruma Cemiyeti Azaları Köylüler Arasında (Ulus, 21 Mart 1942) ${ }^{14}$

\footnotetext{
${ }^{14}$ Fotoğrafın nerede çekildiği ve fotoğrafta kimlerin yer aldığına dair gazetede bir bilgi yer almamaktadır.
} 